Fahira Fejzić Čengić

\title{
RELIGIJE U SVIJETU ${ }^{1}$
}

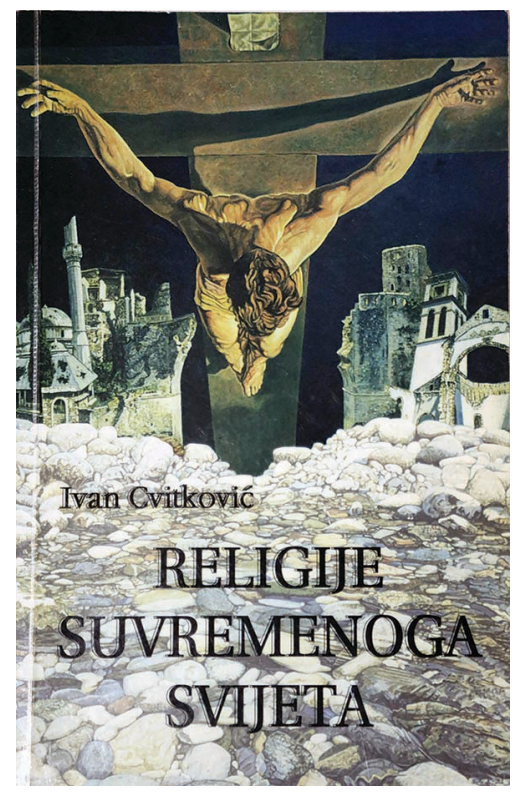

Dugogodišnji profesor Fakulteta političkih nauka dr. Ivan Cvitković, jedan od najpriznatijih sociologa religije na ovim našim prostorima, nakon izvjesne vremenske stanke (vjerovatno uzrokovane ranim ratnim i poratnim (ne)prilikama), objavio je recentan udžbenički materijal istoimenog naslova o religijama savremenoga svijeta. Mada je knjiga nastala kao rezultat predavanja studentima Odsjeka za žurnalistiku, dakle budućim novinarima, nema sumnje da je ona dobrodošla svakome od nas koji od prve znamo što je religija. I dakako da je zanimljivo i jednima i drugima iščitati što je to primjerice karakteristično za egzoteričke afričke religije, za sikhizam ili lamaizam, ali jednako tako nas ova knjiga može ad hoc obavijestiti o tome šta je to moralno sa stajališta sociologije religije kod protestantizma, židovstva ili pak islama.

Nakon što je u deset poglavlja sistematski, ali kroki, boldirao hinduizam, džainizam, budhizam, konfučijanstvo, taoizam, lamaizam, shintoizam, židovstvo, kršćanstvo (rimokatoličanstvo, pravoslavlje, protestantizam), religije američkih Indijanaca, crnačke religije, religije Oceanije i dakako nove religijske pokrete, autor zaključuje ovu knjigu propitujućim desetim poglavljem - šta traži profesionalni moral od novinara? - i sljedećim modifikacijama odgovara: tolerantnost, podršku slobodi mišljenja, otvorenost. Autor, potpuno otvoren za velike različitosti religija na kraju 20. stoljeća, trezvenom rukom i hladnom glavom insistira na potpunoj slobodi vjeroispovijesti i savjesti, na "nediranju u religijsku osjetljivost", podsjećajući sa koliko žestine religijska netrpeljivost samo i samo vodi u "religijsku netrpeljivost, progonstvo, rat i

\footnotetext{
${ }^{1}$ Prikaz knjige Religije suvremenoga svijeta, Ljiljan, 11-18. 10. 1999, str. 41.
} 
smrti". Toliko puta već viđene slike realnosti homo sapiensa i homo politicu$s a$ s oboda na kojima se dodiruju različite civilizacijske i vjerske grupe ljudi. I čemu smo na ovom rovitom balkanskom podneblju u ovo protičuće desetljeće itekako pouzdani svjedoci. Autor budućim novinarima preporučuje krunsko načelo tretmana religije - a ono se sastoji u tome da se novinar nikada neće upuštati da "ocjenjuje koja je religija najbolja ... pošto su sve religije dobre ako su dobri i pošteni oni koji ih slijede." (Ramakrišne). Čini se ipak, da je sa stajališta znanstvene objektivnosti profesor Cvitković mogao još značajnije apostrofirati ovu svojevrsnu "pohvalu objektivnosti u novinarskome poslu", akceptirajući tako mnogo primjera kojima smo zagušeni.

Također, ostaje potrebno da se ovakav udžbenik proširi u egzaktnijim pokazateljima od puke statističke (iz)brojivosti, kao i sa više istraživačkih pokazatelja o kretanjima pojedinih religijskih grupa.

Treba svakako kazati i to da se niko u Sarajevu toliko dugo, razložno, trezveno i nadasve sociološki hladno ne bavi fenomenom religije kod čovjeka dvadesetog stoljeća poput profesora Cvitkovića i da je začuđujuće koliko je malo "eksploatiran" ovaj sarajevski profesor Fakulteta političkih nauka. A mogao se pojaviti i pojavljivati na mnogo mjesta, i u toliko prilika na kojima je imao štošta reći, barem an generale o religijama savremenog svijeta, pa time i Bosne i Hercegovine. Od Sarajeva do Mostara naročito. Doduše, sociologija kao nauka o društvenim pojavama, i njeni aksiomi, ma kako značajni i djelotvorni bili, ako se prepoznaju na vrijeme, obično dolaze na samom kraju društvenih procesa, ma koliko duboki bili i ma koliko kasnili. 